\title{
TIBIOTARSAL COMPRESSION ARTHRODESIS USING A LATERAL LOCKING PLATE
}

\section{ARTRODESE TIBIOTÁRSICA COMPRESSIVA COM O USO DE PLACA BLOQUEADA LATERAL}

Michael J. Coughlin', Caio Nery², Daniel Baumfeld ${ }^{3}$, James Jastifer $^{4}$

\section{ABSTRACT}

Objectives: Tibiotalar (TT) arthrodesis is still a very important option in the treatment of primary or post-traumatic arthritis of the ankle but persists the controversy regarding the optimal method for the fixation of the arthrodesis site. No matter the implant used, the goal is to obtain a solid, healthy, pain-free fusion. The purpose of the current study is to present the preliminary results of a novel laterally based tibiotalar compression arthrodesis system using a locked plate. Methods: Thirteen consecutive patients with tibiotalar arthritis were submitted to an arthrodesis using a new lateral plating system. The average age was 59.7 years (range 36 72); nine patients were male and four female. Using a cutting guide, the remaining articular surfaces of the tibia and talus were removed. A compression device was applied to avoid malalignment of the ankle and a precontoured lateral locking plate was used to achieve the joint fusion. Results: Both the AOFAS ankle-hindfoot score and the VAS score improved with the surgery. All patients' ankles fused by 6 months. In all patients we found a very good alignment in the sagittal, coronal and transverse planes. Conclusion: We believe that a combination of a bilateral compression, contoured bony cuts, and lateral locked plating offers a novel, accurate and useful technique for ankle arthrodesis.

\section{RESUMO}

Objetivos: A artrodese tibiotársica (TT) continua sendo uma importante opção no tratamento da artrose primária ou pós-traumática do tornozelo mas persiste ainda a controvérsia sobre o melhor método de fixação do foco de artrodese. Independentemente do tipo de material utilizado, o objetivo maior é a obtenção da fusão articular sólida, saudável e indolor. O propósito do presente estudo é apresentar os resultados preliminares de um novo sistema de placa bloqueada lateral compressiva para a artrodese do tornozelo. Método: Treze pacientes consecutivos portadores de artrose tibiotársica foram submetidos à artrodese do tornozelo nove pacientes eram homens e quatro mulheres. Com o auxílio de um guia, as superficies articulares do talo e da tíbia foram decorticadas. Um sistema de compressão foi aplicado para evitar o alinhamento indesejável dos segmentos e uma placa bloqueada pré-moldada lateral foi utilizada para obter a fusão articular. Resultados: Tanto o escore AOFAS quanto o VAS melhoraram com a cirurgia. Todos os tornozelos operados consolidaram dentro do prazo de seis meses. Em todos os pacientes, foi obtido um ótimo alinhamento nos planos sagital, coronal e transverso. Conclusão: Acreditamos que a combinação de compressão bilateral, cortes ósseos com contornos pré-demarcados e placa lateral bloqueada, constitui uma técnica moderna, segura e útil para a artrodese do tornozelo.

Descritores - Artrodese, Traumatismos do Tornozelo; Placas Ósseas ankle arthroplasty, and ankle distraction arthroplasty. Patients who have persistent, functionally disabling ankle-joint pain despite exhaustive nonoperative treatment and an unaffected subtalar joint may benefit from an ankle arthrodesis. fficult challenge to both patients and clinicians. The main surgical treatment options include ankle arthrodesis, total

1 - Past-president, American Orthopaedic Foot and Ankle Society Past-president, International Federation of Foot and Ankle Societies. Director, St. Alphonsus Foot and Ankle Clinic - Boise, USA.

2 - Associate Professor - UNIFESP - Escola Paulista de Medicina; President, Federación Latinoamericana de Cirugia de la Pierna y Pié; Board of Directors, IFFAS - International Federation of Foot and Ankle Societies; Past-president, ABTPé - Associação Brasileira de Tornozelo e Pé - São Paulo, SP, Brazil.

3 - Foot and Ankle Surgeon - Hospital Felício Rocho -Belo Horizonte, MG, Brazil.

4 - Foot and Ankle Surgeon - Michigan State University Kalamazoo Center of Medical Studies - Kalamazoo, USA.

Work performed at the St. Alphonsus Regional Medical Center the Coughlin Clinic - Boise, USA.

Correspondece: St. Alphonsus Regional Medical Center. The Coughlin Clinic, 901 N Curtis Rd, Suite 503 - Boise, ID 3706-1343, USA. E-mail: caionerymd@gmail.com Trabalho recebido para publicação: 02/09/2011, aceito para publicação: 22/11/2011.

Os autores declaram inexistência de conflito de interesses na realização deste trabalho / The authors declare that there was no conflict of interest in conducting this work 
First described in 1882, ankle arthrodesis has become a popular treatment for degenerative arthritis ${ }^{(1)}$. In 1951, the technique of compression arthrodesis of the ankle was first introduced by Charnley ${ }^{(2)}$ who used an external fixation device. External fixation has become less popular in recent decades except for those with open ankle injuries, infection, or severe deformity ${ }^{(3,4)}$. Because of a lower risk of complications, arthrodesis has been performed utilizing an open or arthroscopic debridement most commonly using internal fixation with screws ${ }^{(5-13)}$.

A recent biomechanical study has shown superior stability of an ankle fusion using internal fixation with a plate and screws versus fixation with screws alone ${ }^{(14)}$.

Several authors have reported successful use of internal fixation with plates and screws utilizing various techniques including lateral plating, anterior dual plating and custom blade plate techniques ${ }^{(15-19)}$. Three additional studies report using anterior tension plate techniques for tibiotalar arthrodesis after failed total ankle arthroplasty ${ }^{(20-22)}$.

Traditionally, ankle arthrodesis complication rates of up to $60 \%$ and nonunion rates between $5 \%$ and $37 \%$ have been reported in studies that range in size from 17-54 patients, however more recent results have shown substantially better functional outcomes with nonunion rates consistently around $10-13 \%$ or lower in studies that range in size from 19-81 patients ${ }^{(12,18,23-37)}$.

The improved results seen in recent years may be due to a better understanding of the optimum position for the ankle arthrodesis. The preferred position for an ankle arthrodesis is thought to be neutral in the sagittal plane with regards to plantarflexion and dorsiflexion, from neutral to slight valgus (5 degrees) in the coronal plane, between 5 and 10 degrees of external rotation in the horizontal plane, and the talus centered exactly below the tibia (neutral translation $)^{(23,35,38,39)}$.

The purpose of the current study is to present the preliminary results (with a minimum of six months follow-up) of a novel laterally based tibiotalar compression arthrodesis system using a locked plate.

\section{METHODS}

The first thirteen consecutive patients undergoing tibiotalar arthrodesis using a new lateral plating system were retrospectively enrolled in this study. Institutional Review Board approval was fist obtained for the study. All arthrodesis were performed by the senior author (MJC).

The surgical indications included tibiotalar arthritis with sparing of the subtalar joint. This arthritis was secondary to trauma in all but three patients. Of the three other patients, one had a failed osteochondral autograph transplant, one a failed previous attempt at arthrodesis and one patient who developed arthritis following an infection after a previous open reduction and internal fixation of an ankle fracture.

The average age of the patients were 59.7 (range 36-72). Nine patients were male and four were female. One patient was lost to follow-up. Minimum follow up was six months. Patients were evaluated both clinically and with weight bearing radiographs. All patients had AOFAS ankle-hindfoot scores as well as a Visual Analog Scale (VAS) available preoperatively and at latest follow-up. The average time of follow-up was 8.6 months (range 6.0-12.1).

Alignment was assessed in the following ways. Measurements were obtained to assess for post-operative rotation, translation, alignment in the sagittal plane (plantarflexion/dorsiflexion) and alignment in the coronal plane (varus/valgus). For alignment in the sagittal plane, both radiographic and clinical examination were used. Radiographically the longitudinal axis of the tibia was measured with mid-diaphyseal reference points placed on the lateral radiograph. A second line was drawn from the inferior aspect of the calcaneus to the plantar border of the tibial sesamoid. The intersection of these two lines formed an angle that described the magnitude of plantarflexion/dorsiflexion. Clinically, the included angle formed between the longitudinal axis of the fibula and the plantar lateral border of the foot was measured during weight bearing. For rotation, a clinical angular measurement was taken in the axial plane from the tibial tubercle to a line bisecting the heel and the third toe. This was then compared to the contralateral side. Translation was assessed on the lateral radiograph. Coronal plane alignment was measured from a photograph obtained from behind while the patient was weight bearing. A vertical line drawn from the center of the posterior calf and ankle was then compared with a line drawn down the center of the calcaneus ${ }^{(40)}$. This ankle measured the magnitude of varus/valgus.

\section{OPERATIVE TECHNIQUE}

Surgery was performed with a combined regional nerve block and general anesthesia in most cases. The 
patients were placed in a semi-supine position with a thigh tourniquet. A lateral longitudinal incision was utilized and the fibula was dissected, and osteotomized fifteen centimeters above the tip of the fibula, removed, and morselized for use as autogenous bone graft. A cutting guide was used that matches the arc of the tibiotalar joint (Figure 1A-D). It was fixed to the tibia and talus, multiple drill holes were created from lateral to medial, and the remaining articular surfaces were removed. The tibial and talar surface were debrided of any remaining osteophytes and cartilage. The curved cutting guide allows for both rotational and coronal plane control of the cut surfaces. Using
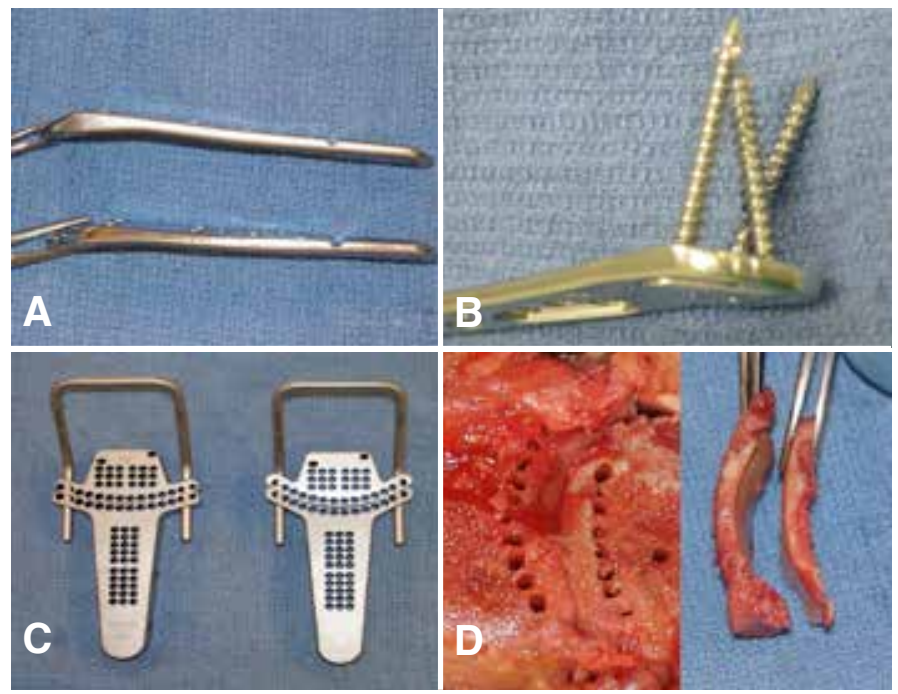

Figure 1 - Two plate flare angles shown in $(A)$ and $(B)$ showing the varied fixed angle constraint of the distal screw-plate interface. (C) shows the two different radii of curvature of the cutting jig to match the patient's anatomy and $(D)$ the bone preparation. pin fixation, distractors can be placed to visualize and prepare the joint surfaces. A separate medial incision was utilized on occasion to prepare the medial gutter and osteotomize the medial malleolus when necessary. Once the joint surfaces were prepared, a compression device was applied through pins placed through the tibia and talus from medial to lateral in order to avoid varus/valgus malalignment which may occur by compressing from only one side. A posterior foot holding device was used to ensure the ankle was neutral in the sagittal plane. The laterally based precontoured locking plate was then applied. Screws were sequentially placed first in the talus, and the locking cap was added (Figure 2A-H). Then compression of the ankle arthrodesis was applied, and the tibial screws were placed, and a second locking cap was applied. Care was taken to ensure the subtalar joint was free of hardware by utilizing fluoroscopy intraoperatively. In several cases, an anterolateral or anterior medial tension band type plate or screw was applied for additional strength. The wounds were closed in layers over a medium hemovac drain. A below knee splint was applied.

All patients were admitted to the hospital following surgery, and at discharge on the second post-operative day, the lower extremity was placed into a below-knee cast. The cast was changed every three weeks. Patients were maintained non-weight bearing in a below-knee cast for 6 weeks, followed by another 6 week period in a below-knee walking cast.
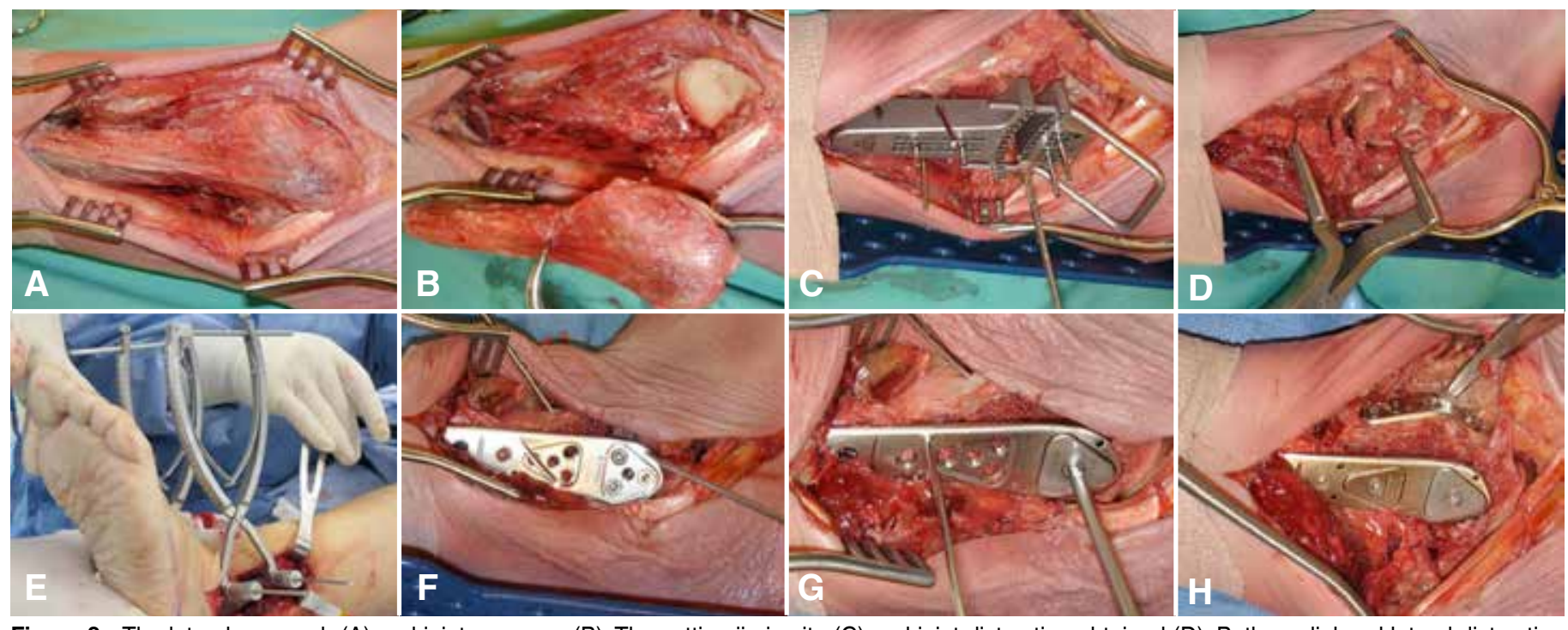

Figure 2 - The lateral approach (A) and joint exposure (B). The cutting jig in situ (C) and joint distraction obtained (D). Both medial and lateral distraction is obtained $(E)$. $(F)$ shows the plate provisionally fixed with kirschner wires while the distal screws are sequentially placed followed by the locking cap (G) and an anterior tension band plate $(\mathrm{H})$ if needed. 


\section{RESULTS}

The average AOFAS ankle-hindfoot score improved from 42 points pre-operatively (range 21-61) to 71 points post-operatively (range 39-96). The average VAS score improved from 8 (range 6-10) pre-operatively to 3 (range 0-10) post-operatively. All patients ankles fused radiographically by 6 months (Figure 3A-D). One patient required a subsequent procedure for an incision breakdown which subsequently healed without sequela.

Sagittal plane alignment varied from 15 degrees of dorsiflexion to 12 degrees of plantarflexion radiographically with a mean of 1.6 degrees of dorsiflexion. Clinically, sagittal alignment varied from 10 degrees of dorsiflexion to 8 degrees of plantarflexion with a mean of 1.4 degrees of dorsiflexion. Coronal plane alignment
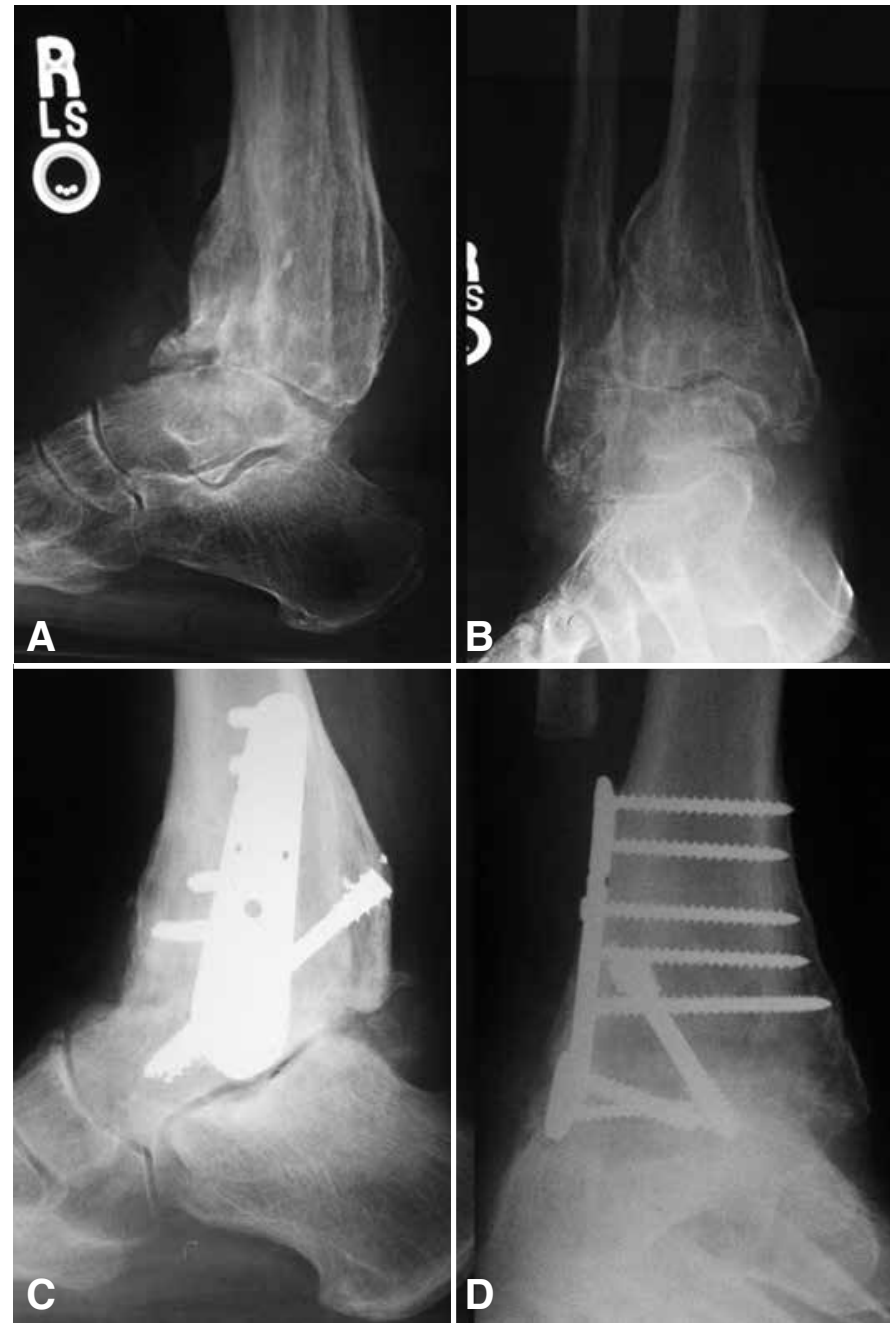

Figure 3 - 61 year old male patient presented with post-traumatic tibio-talar arthritis with pain and deformity. (A) The preoperative radiographs considerable deformity including anterior translation of the talus relative to the tibia and (B) varus deformity in the coronal plane. (C) Lateral and (D) $\mathrm{AP}$ weightbearing radiographs taken at 18 months follow up after corrective arthrodesis and successful fusion. varied from 0-15 degrees of valgus with a mean of 8.9 degrees of valgus compared to 7.5 on the contralateral side. Rotation varied clinically from 0-5 degrees of external rotation compared to the contralateral side with a mean of 0.6 degrees of external rotation. No patients showed radiographic evidence of translation.

\section{DISCUSSION}

Treatment of patients with disabling arthritis, pain, and deformity of the ankle remains a challenging problem. The surgical goals of the tibiotalar arthrodesis are to eliminate pain and provide a stable, plantigrade foot for ambulation.

This study, to the best of the authors' knowledge, represents the only recent description of tibiotalar arthrodesis using a lateral plate and the only description of a technique utilizing both medial and lateral compression combined with locking plate technology. In our opinion, the combination of a laterally based locking plate, medial and lateral compression combined with curved bony resection allow for excellent control of the four planes of possible motion; these include motion in the sagittal plane, coronal plane, axial rotation and translation. This is supported by previous observations that preservation of the bony contour allows for accurate control of rotation, translation and coronal plane alignment, which are all thought be important for a good long term outcome ${ }^{(11,41)}$.

The current study had no nonunions, one minor complication, and significant improvement in AOFAS ankle hindfoot scores although we expect the scores to improve as we follow these patients over the next year. However, these results compare favorably with recent studies in these regards ${ }^{(18,24,29,30-37)}$.

The limitations of this study include the low sample size, the relatively short term follow-up, the retrospective nature and the fact that it is a single surgeon and single site study. Additionally, the patient population may have been biased towards a greater deformity than the general ankle arthritis population because none of the current study population received a total ankle arthroplasty which are routinely performed at the study institution.

\section{CONCLUSION}

In conclusion, we believe that a combination of bilateral compression, contoured bony cuts, and lateral locked plating offers a novel, accurate, and useful technique for performing ankle arthrodesis. 


\section{REFERENCES}

1. Albert E. Einige Fale von kunstlicher Ankylosen bildung an paralytischen Gliedmassen. Wiener medizinische Presse. 1882;23:725.

2. Charnley J. Compression arthrodesis of the ankle and shoulder. J Bone Joint Surg Br. 1951;33(2):180-91.

3. Pfahler M, Krodel A, Tritschler A, Zenta S. Role of internal and external fixation in ankle fusion. Arch Orthop Trauma Surg. 1996;115(3-4):146-8.

4. Pinzur MS. The role of ring external fixation in Charcot foot arthropathy. Foot Ankle Clin. 2006;11(4):837-47.

5. Zwipp H, Grass R, Rammelt S, Dahlen C. [Arthrodesis - non-union of the ankle. Arthrodesis failed]. Chirurg. 1999;70(11):1216-24.

6. Thordarson DB, Markolf K, Cracchiolo A 3rd. Stability of an ankle arthrodesis fixed by cancellous-bone screws compared with that fixed by an external fixator. A biomechanical study. J Bone Joint Surg Am. 1992;74(7):1050-5.

7. Coester LM, Saltzman CL, Leupold J, Pontarelli W. Long-term results following ankle arthrodesis for post-traumatic arthritis. J Bone Joint Surg Am. 2001;83-A(2):219-28.

8. Moeckel BH, Patterson BM, Inglis AE, Sculco TP. Ankle arthrodesis. A comparison of internal and external fixation. Clin Orthop Relat Res. 1991;(268):78-83.

9. Endres T, Grass R, Rammelt S, Zwipp H. [Ankle arthrodesis with four cancellous lag screws]. Oper Orthop Traumatol. 2005;17(4-5):345-60.

10. Hansen S. Functional reconstruction of the foot and ankle. Philadelphia: Lippincott Williams \& Wilkins; 2000.

11. Morgan CD, Henke JA, Bailey RW, Kaufer $\mathrm{H}$. Long-term results of tibiotalar arthrodesis. J Bone Joint Surg Am. 1985;67(4):546-50.

12. Ogilvie-Harris DJ, Lieberman I, Fitsialos D. Arthroscopically assisted arthrodesis for osteoarthrotic ankles. J Bone Joint Surg Am. 1993;75(8):1167-74

13. Winson IG, Robinson DE, Allen PE. Arthroscopic ankle arthrodesis. J Bone Joint Surg Br. 2005;87(3):343-7.

14. Kakarala G, Rajan DT. Comparative study of ankle arthrodesis using cross screw fixation versus anterior contoured plate plus cross screw fixation. Acta Orthop Belg. 2006;72(6):716-21.

15. Braly WG, Baker JK, Tullos HS. Arthrodesis of the ankle with lateral plating. Foot Ankle Int. 1994;15(12):649-53.

16. Sowa DT, Krackow KA. Ankle fusion: a new technique of internal fixation using a compression blade plate. Foot Ankle. 1989;9(5):232-40.

17. Wera GD, Sontich JK. Tibiotalar arthrodesis using a custom blade plate. J Trauma. 2007;63(6):1279-82.

18. Plaass $C$, Knupp M, Barg A, Hintermann B. Anterior double plating for rigid fixation of isolated tibiotalar arthrodesis. Foot Ankle Int. 2009;30(7):631-9.

19. Ross SD, Matta J. Internal compression arthrodesis of the ankle. Clin Orthop Relat Res. 1985;(199):54-60.

20. Mears DC, Gordon RG, Kann SE, Kann JN. Ankle arthrodesis with an anterior tension plate. Clin Orthop Relat Res. 1991;(268):70-7.

21. Zwipp H, Grass R. [Ankle arthrodesis after failed joint replacement]. Oper Orthop Traumatol. 2005;17(4-5):518-33.

22. Culpan $P$, Le Strat $V$, Piriou $P$, Judet $T$. Arthrodesis after failed total ankle replacement. J Bone Joint Surg Br. 2007;89(9):1178-83..
23. Buck P, Morrey BF, Chao EY. The optimum position of arthrodesis of the ankle. A gait study of the knee and ankle. J Bone Joint Surg Am. 1987;69(7):1052-62.

24. Fuchs S, Sandmann C, Skwara A, Chylarecki C. Quality of life 20 years after arthrodesis of the ankle. A study of adjacent joints. J Bone Joint Surg Br. 2003;85(7):994-8.

25. Johnson EW Jr, Boseker EH. Arthrodesis of the ankle. Arch Surg. 1968;97(5):766-73.

26. Hagen RJ. Ankle arthrodesis. Problems and pitfalls. Clin Orthop Relat Res. 1986;(202):152-62.

27. Miehlke W, Gschwend N, Rippstein P, Simmen BR. Compression arthrodesis of the rheumatoid ankle and hindfoot. Clin Orthop Relat Res. 1997;(340):75-86.

28. Glick JM, Morgan CD, Myerson MS, Sampson TG, Mann JA. Ankle arthrodesis using an arthroscopic method: long-term follow-up of 34 cases. Arthroscopy. 1996;12(4):428-34.

29. Haddad SL, Coetzee JC, Estok R, Fahrbach K, Banel D, Nalysnyk L. Intermediate and long-term outcomes of total ankle arthroplasty and ankle arthrodesis. A systematic review of the literature. J Bone Joint Surg Am. 2007;89(9):1899-905.

30. Mann RA, Rongstad KM. Arthrodesis of the ankle: a critical analysis. Foot Ankle Int. 1998;19(1):3-9.

31. Takakura Y, Tanaka Y, Sugimoto K, Akiyama K, Tamai S. Long-term results of arthrodesis for osteoarthritis of the ankle. Clin Orthop Relat Res. 1999;(361):178-85.

32. Buchner M, Sabo D. Ankle fusion attributable to posttraumatic arthrosis: a long-term followup of 48 patients. Clin Orthop Relat Res. 2003;(406):155-64.

33. Ferkel RD, Hewitt M. Long-term results of arthroscopic ankle arthrodesis. Foot Ankle Int. 2005;26(4):275-80.

34. Kopp FJ, Banks MA, Marcus RE. Clinical outcome of tibiotalar arthrodesis utilizing the chevron technique. Foot Ankle Int. 2004;25(4):225-30.

35. Thomas R, Daniels TR, Parker K. Gait analysis and functional outcomes following ankle arthrodesis for isolated ankle arthritis. J Bone Joint Surg Am.2006;88(3):526-35.

36. Smith R, Wood PL. Arthrodesis of the ankle in the presence of a large deformity in the coronal plane. J Bone Joint Surg Br. 2007;89(5):615-9.

37. Flückiger $\mathrm{G}$, Weber $\mathrm{M}$. [The transfibular approach for ankle arthrodesis]. Oper Orthop Traumatol. 2005;17(4-5):361-79.

38. Hefti FL, Baumann JU, Morscher EW. Ankle joint fusion -- determination of optimal position by gait analysis. Arch Orthop Trauma Surg. 1980;96(3):187-95.

39. Mazur JM, Schwartz E, Simon SR. Ankle arthrodesis. Long-term follow-up with gait analysis. J Bone Joint Surg Am. 1979;61(7):964-75.

40. Coughlin MJ, Kaz A. Correlation of Harris mats, physical exam, pictures, and radiographic measurements in adult flatfoot deformity. Foot Ankle Int. 2009;30(7):604-12.

41. Kennedy JG, Hodgkins CW, Brodsky A, Bohne WH. Outcomes after standardized screw fixation technique of ankle arthrodesis. Clin Orthop Relat Res. 2006;447:112-8 